\title{
INTERNET OF THINGS (IoT) PADA PROTOTIPE PENDETEKSI KEBOCORAN GAS BERBASIS MQ-2 dan SIM800L
}

\author{
SRI MULYATI ${ }^{1)}$ \& SUMARDI ${ }^{2)}$ \\ Program Studi Teknik Informatika ${ }^{1)}$, Program Studi Elektro ${ }^{2)}$ \\ Fakultas Teknik Universitas Muhammadiyah Tangerang \\ Jl. Perintis Kemerdekaan 1/33 Cikokol Kota Tangerang \\ Email: lilysrimulyati@gmail.com ${ }^{1)}$, mardiesadi99@gmail.com ${ }^{2}$
}

\begin{abstract}
The use of the Internet of Things is currently becoming popular, using communicating objects. Likewise in the context of gas. To find out gas leakage and early detection of gas leakage, a prototype gas leak detector was made using MQ-2 and SIM800L. This gas detector uses Arduino nano, gas sensors (MQ-2), RFID, 16x2 and i2c LCDs, Buzzers, and SIM800L modules. as a wireless connection using SMS. The method used in this study is the experimental method. This tool is implemented and processed on hardware and provides the right and expected results. Gas Leaks will be detected on gas levels starting at $52 \%$.
\end{abstract}

Keywords: Arduino Nano, SIM800L, GSM Module, Gas Sensor.

\begin{abstract}
ABSTRAK
Penggunaan Internet of Things saat ini menjadi popular, setelah penggunaan benda dengan manusia bisa berkomunikasi, atau benda dengan benda berkomunikasi. Demikian juga penerapan pada keamanan dalam mengantisipasi terjadinya kebakaran akibat keboroan gas elpiji. Untuk memantau kebocoran gas serta pendeteksi dini akibak kebocoran gas dibuatlah prototipe pendeteksi kebocoran gas dengan menggunkan MQ-2 dan SIM800L Alat pendeteksi gas ini menggunakan Arduino nano, Sensor gas ( MQ-2), RFID, Lcd 16x2 dan i2c, Buzzer,dan modul SIM800L sebagai koneksi wireless menggunakan sms. Metode yang digunakan pada penelitian alat ini menggunakan metode eksperimen. Alat ini diimplementasikan dan di uji pada perangkat keras dan memberikan hasil yang tepat dan diharapkan. Gas Bocor akan terdeteksi pada Kadar gas mulai $52 \%$.
\end{abstract}

Kata Kunci: Arduino Nano, SIM800L, Modul GSM, Sensor Gas,

\section{PENDAHULUAN}

Internet merupakan sumber informasi dan komunikasi yang sangat popular dewasa ini. Komunikasi dengan benda dapat dilakukan melalui internet dikenal dengan nama Internet of Things (IoT) (David et al. 2015). IoT pada era industry 4.0 merupakan revolusi internet, dimana manusia bisa berinterkasi dengan mesin, demikian juga mesin dengan mesin bisa saling berkomunikasi (Alfuqaha et al. 2015). Internet of Things adalah jaringan global yang dinamis infrastruktur dengan kemampuan mengkonfigurasi diri berdasarkan protokol komunikasi standar dan interoperabel di mana "hal-hal" fisik dan virtual memiliki identitas, atribut fisik, dan kepribadian virtual dan menggunakan antarmuka cerdas, dan terintegrasi dengan mulus ke dalam jaringan informasi, sering mengkomunikasikan data yang terkait dengan pengguna dan lingkungannya ( $\mathrm{P}$ dan Vanamala. 2018).

Pemakaian gas elpiji sangat praktis dan mudah di dapat, namun dalam hal pemakaian- 
nya perlu waspada dengan system keamanan yang handal. Dalam hal ini tidak lepas dengan bahaya kebocoran gas, oleh karena itu perlu dilakukan pengaman dengan pedeteksi kebocoran gas eliji secada diri. Telah banyak yang melakukan rancang bangun pendeteksi kebocoran gas ini. Kebocoran gas dapat didetek-si dengan menggunakan: ESP8266 (Roihan at al. 2016), sensor gas MQ-2 (Erlansyah, 2014 ;Yanti, n.d.), MQ-7 (Prakoso \& Rakhmawati, 2018), MQ-8 (Isnaini, 2013) , TGS2610 (Amalia \& Aprilianto, n.d.), bahkan ada yang menggunkan robot hexapoda (Avrilyantama et al. 2015), SMS (Widarto et al. 2012), dan kombinasi darai MQ-2 dan SMS (Nasional et al. 2016 ; Joko \& Nurul, 2013; Barovih et al. 2016; Dewi et al. 2017; Soemarsono, et al. 2015; Saefullah et al. 2012)

Dalam Penelitian ini, membuat sebuah prototipe pedeteksi kebocoran gas dengan bentuk dan ukuran sekecil mungkin, dengan menggunkan alat mikrokontroler Arduino nano, ensor gas MQ-2 dan GSM Modul SIM800L Alat Pendeteksi Kebocoran Gas LPG ini bekerja mendeteksi gas yang bocor dan memberikn informasi melalui SMS (Short Message Service). Alat ini diharapkan dapat digunakan sebagai alat pengaman yang cukup murah dan mudah dibuat dan digunkan oleh masyarakat.

Batasan masalah dalam penelitian ini antara lain 1) Pada alat proteksi kebocoran gas LPG ini hanya menggunakan satu sensor yaitu sensor gas jenis MQ-2, 2) Pendeteksian hanya dilakukan pada satu titik saja, 3) Jarak sumber gas dengan sensor pendeteksi tidak ditentukan, 4) Nilai batas aman kadungan gas di udara ditentukan sendiri oleh penulis berdasarkan nilai ADC Sensor.

Tujuan dari penelitian ini anatara lain 1) Merancang suatu alat yang dapat mendeteksi keberadaan gas LPG didalam suatu ruangan tertutup seberti dapur rumah tangga, 2) Mengimplementasikan sistem kendali pada alat pendeteksi kebocoran gas LPG, 3) Mengetahui fungsi dan karakteristik sensor berdasarkan pengujian yang dilakukan.

\section{TINJAUAN PUSTAKA \\ a. Mikrokontroler}

Arduino adalah sebuah board mikrokontroller yang berbasis Atmega328. Arduino memiliki 14 pin input/output yang mana 6 pin dapat digunakan sebagai output PWM, 6 pin analog input, crystal osilator $16 \mathrm{MHz}$, koneksi USB, jack power, kepala ICSP, dan tombol reset. Arduino mampu men-support mikrokontroller dan dapat dikoneksikan dengan komputer menggunakan kabel USB.

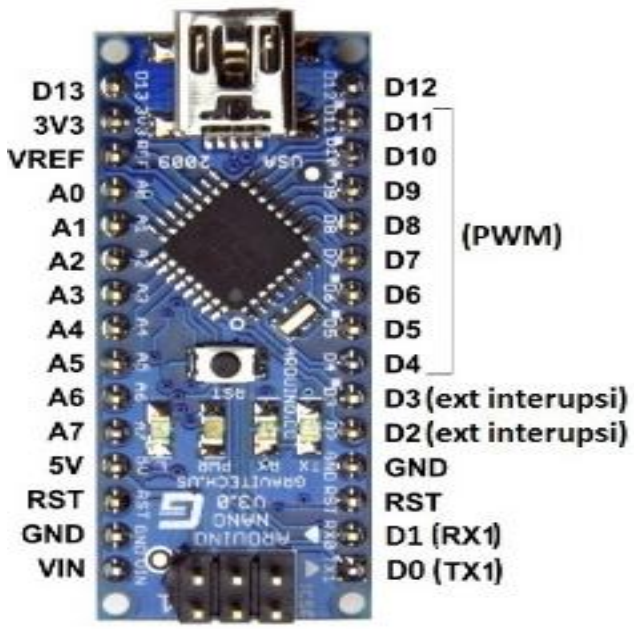

Gambar 1 Board Arduino Nano.

Arduino Nano memiliki kelebihan tersendiri dibandingkan mikrokontroller lain, selain bersifat open source, arduino juga mempunyai bahasa pemrogramannya sendiri yang berupa bahasa C. Selain itu dalam board arduino nano sendiri sudah terdapat loader yang berupa USB sehingga memudahkan ketika memprogram mikrikontroller didalam arduino. Sedangkan pada kebanyakan board mikrokontroller yang lain masih membutuhkan rangkaian loader terpisah untuk memasukkan program ketika memprogram mikrokontroller tersebut. Port USB tersebut selain untuk loader ketika memprogram, bisa juga difungsikan sebagai port komunikasi serial.

Arduino nano menyediakan 20 pin I/O yang terdiri dari 6 pin input analog dan 14 pin digital input/output (gambar 1). Untuk 6 pin analog sendiri bisa juga difungsikan sebagai output digital jika diperlukan output digital tambahan selain 14 pin yang sudah tersedia. Untuk mengubah pin analog menjadi pin digital cukup mengubah konfigurasi pin pada program. Dalam board bisa dilihat pin digital diberi keterangan 0-13, jadi untuk menggunakan pin analog menjadi output digital, pin analog yang pada keterangan board 0-5 diubah menjadi pin 14-19. Dengan kata lain pin analog 0-5 berfungsi juga sebagai pin output digital 14-19. 


\section{b. Spesfikasi Arduino Nano}

Arduino Nano memiliki spesifikasi sebagai berikut:

\begin{tabular}{|c|c|c|}
\hline Mikrokontroller & & $\begin{array}{l}\text { Atmel ATmegal68 untuk Arduino } \\
\text { Nano 2.x Atmer Atmega328 untuk } \\
\text { Arduino Nano 3.x }\end{array}$ \\
\hline Tegangan kerja & $:$ & 5 Volt \\
\hline Tegangan input & : & Optimal: $7-12$ Volt \\
\hline Minimum & : & 6 Volt \\
\hline Maksimum & : & 20 Volt \\
\hline Digital pin $\mathrm{V} / \mathrm{O}$ & : & $\begin{array}{l}14 \text { pin yaitu pin } D 0 \text { sampai pin D13, } \\
\text { Dilengkapi dengan } 6 \text { pin PWM }\end{array}$ \\
\hline Analog pin & : & 8 pin yaitu pin A0 sampai pin $A 7$ \\
\hline $\begin{array}{l}\text { Arus listrik } \\
\text { maksimum }\end{array}$ & : & $40 \mathrm{~mA}$ \\
\hline Flash memori & : & $\begin{array}{l}32 \text { Mbyte untuk Arduino Nano } 3 . x \text {, } \\
16 \text { Mbyte untuk Arduino Nano 2.x }\end{array}$ \\
\hline SRAM & : & $\begin{array}{l}1 \text { kbyte (ATmega168) dan } 2 \text { kbyte } \\
\text { (ATmega328) }\end{array}$ \\
\hline EEPROM & : & $\begin{array}{l}512 \text { byte (Atmega168) dan } 1 \text { kbyte } \\
\text { (Atmega328) }\end{array}$ \\
\hline Kecepatan clock & : & $16 \mathrm{MHz}$ \\
\hline Ukuran board & : & $4,5 \mathrm{~mm} \times 18 \mathrm{~mm}$ \\
\hline Berat & : & 5 gram \\
\hline
\end{tabular}

c. Daya

Arduino Nano dapat menggunakan catudaya langsung dari mini-USB port atau menggunakan catudaya luar yang dapat diberikan pada pin30 (+) dan pin29 (-) untuk tegangan kerja $7-12 \mathrm{~V}$ atau pin $28(+)$ dan pin $29(-)$ untuk tegangan $5 \mathrm{~V}$.

\section{d. Memori}

Atmega 168 dilengkapi dengan flash memori sebesar 16 kbyte yang dapat digunakan untuk menyimpan kode program utama. Flash memori ini sudah terpakai 2 kbyte untuk program boatloader sedangkan Atmega328 dilengkapi dengan flash memori sebesar 32 kbyte dan dikurangi sebesar 2 kbyte untuk boatloader.

Selain dilengkapi dengan flash memori, mikrokontroller ATmega168 dan ATmega 328 juga dilengkapi dengan SRAM dan EEPROM. SRAM dan EEPROM dapat digunakan untuk menyimpan data selama program utama bekerja. Besar SRAM untuk ATmega168 adalah $1 \mathrm{~kb}$ dan untuk ATmega328 adalah $2 \mathrm{~kb}$ sedangkan besar EEPROM untuk ATmega168 adalah 512 b dan untuk ATmega328 adalah $1 \mathrm{~kb}$.

\section{e. Input dan Output}

Arduino Nano mempunyai 14 pin digital yang dapat digunakan sebagai pin input atau output. Pin ini akan mengeluarkan tegangan $5 \mathrm{~V}$ untuk mode $H I G H$ (logika 1) dan $0 \mathrm{~V}$ untuk mode LOW (logika 0) jika dikonfigurasikan sebagai pin output. Jika di konfigu- rasikan sebagai pin input, maka ke 14 pin ini dapat menerima tegangan $5 \mathrm{~V}$ untuk mode HIGH (logika1) dan 0V untuk mode LOW (logika 0). Besar arus listrik yang diijinkan untuk melewati pin digital I/O adalah $40 \mathrm{~mA}$. Pin digital I/O ini juga sudah dilengkapi dengan resistor pull-up sebesar $20-50 \mathrm{k} \Omega$. Ke 14 pin digital I/O ini selain berfungsi sebagai pin I/O juga mempunyai fungsi khusus yaitu:

Pin D0 dan pin D1 juga berfungsi sebagai pin TX dan RX untuk komunikasi data serial. Kedua pin ini terhubung langsung ke pin IC FTDI USB-TTL. Pin D2 dan pin D3 juga berfungsi sebagai pin untuk interupsi eksternal. Kedua pin ini dapat dikonfigurasikan untuk pemicu interupsi dari sumber eksternal. Interupsi dapat terjadi ketika timbul kenaikan atau penurunan tegangan pada pin D2 atau pin D3. Pin D4, pin D5, pin D6, pin D9, pin D10 dan pin D11 dapat digunakan sebagai pin PWM (pulse width modulator). Pin D10, pin D11, pin D12 dan pin D13, ke empat pin ini dapat digunakan untuk komunikasi mode SPI. Pin D13 terhubung ke sebuah LED.

Arduino Nano juga dilengkapi dengan 8 buah pin analog, yaitu pin A0, A1, A2, A3, A4, A5, A6 dan A7. Pin analog ini terhubung ke ADC (analog to digital converter) internal yang terdapat di dalam mikrokontroller. Pada kondisi awal, pin analog ini dapat mengukur variasi tegangan dari $0 \mathrm{~V}$ sampai $5 \mathrm{~V}$ pada arus searah dengan besar arus maksimum $40 \mathrm{~mA}$. Lebar range ini dapat diubah dengan memberikan sebuah tegangan referensi dari luar melalui pin Vref. Pin analog selain dapat digunakan untuk input data analog, juga dapat digunakan sebagai pin digital I/O, kecuali pin A6 dan A7- yang hanya dpat digunakan untuk input data analog saja. Fungsi khusus untuk pin analog antara lain: Pin A4 untuk pin SDA, pin A5 untuk pin SCL, pin ini dapat digunakan untuk komunikasi I2C. Pin Aref digunakan sebagai pin tegangan referensi dari luar untuk mengubah range ADC. Pin reset, pin ini digunakan untuk mereset board Arduino Nano, yaitu dengan menghubungkan pin ini ke ground selama beberapa milidetik. Board Arduino Nano selain dapat direset melalui pin reset, juga dapat direset dengan menggunakan tombol reset yang terpasang pada board Arduino Nano. 


\section{f. Komunikasi}

Arduino Nano sudah dilengkapi dengan beberapa fasilitas untuk komunikasi yang dapat digunakan untuk berkomunikasi dengan komputer (PC atau Laptop), atau dengan board mikrokontroller lainnya. ATmega168 dan ATmega328 dilengkapi dengan komunikasi serial UART TTL (5V), yang terdapat pada pin D0 dan pin D1. Board juga dilengkapi dengan sebuah IC FTDI 232 Rl yang dapat dihubungkan langsung ke komputer untuk menghasilkan sebuah virtual com-port pada operating sistem.

Software Arduino (sketch) yang digunakan sebagai IDE Arduino juga dilengkapi dengan serial monitor yang memungkinkan programmer untuk menampilkan data serial sederhana yang dapat dikirim atau diterima dari board Arduino Nano. Led RX dan TX yang terpasang pada board Arduino Nano akan berkedip jika terjadi komunikasi data serial antara PC dengan Arduino Nano.

Selain dapat berkomunikasi dengan menggunakan data serial melalui virtual comport, Arduino Nano juga dilengkapi dengan mode komunikasi I2C (TWI) dan SPI untuk komunikasi antar hardware (https://djukarna 4arduino.wordpress.com/2015/01/19/arduino -nano/).

\section{f. Sensor $M Q-2$}

Sensor gas asap MQ-2 ini mendeteksi konsentrasi gas yang mudah terbakar di udara serta asap dan output membaca sebagai tegangan analog. Sensor gas asap MQ-2 dapat langsung diatur sensitifitasnya dengan memutar trimpot. Sensor ini biasa digunakan untuk mendeteksi kebocoran gas baik di rumah maupun di industri. Gas yang dapat dideteksi diantaranya: $L P G$, i-butane, propane, methane, alcohol, Hydrogen, smoke (Agung et al. 2009).

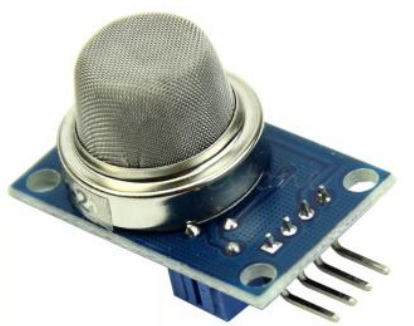

Gambar 2 Sensor Gas MQ-2.

\section{g. LCD $16 \times 2$}

LCD (Liquid Cristal Display) adalah salah satu bagian dari modul peraga yang me- nampilkan karakter yang diinginkan Layar LCD menggunakan dua buah lembaran bahan yang dapat mempolarisasikan dan Kristal cair diantara kedua lembaran tersebut. Kegunaan LCD banyak sekali dalam perancangan suatu sistem dengan menggunakan mikrokontroler. LCD dapat berfungsi menampilkan suatu nilai hasil sensor, menampilkan teks atau menampilkan menu pada aplikasi mikrokontroler (Putra, 2016).

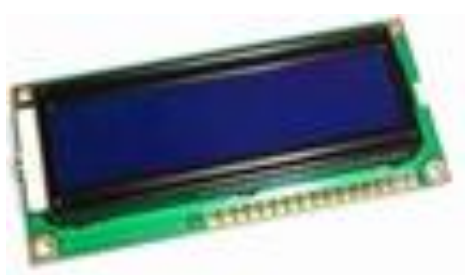

Gambar 3 LCD 16 X 2.

\section{h. Sim800l}

SIMCOM SIM800L V2.0 GSM/GPRS Module adalah module QUAD BAND GSM/GPRS yang kompatibel dengan Arduino, berfungsi untuk menambahkan fitur GSM (voice call, SMS) dan GPRS (Nasional et al. 2016).

Kelebihan modul ini adalah Vcc dan TTL level serialnya sudah $5 \mathrm{~V}$ sehingga bisa langsung anda hubungkan ke Arduino atau minsys lainnya yang mempunyai level $5 \mathrm{~V}$. Banyak modul GPRS/GSM yang beredar dipasaran perlu penambahan regulator $5 \mathrm{~V}$ dan rangkaian level converter, sedangkan modul yang kami tawarkan ini sudah memiliki rangkaian builtin regulator + TTL level converter diboardnya.

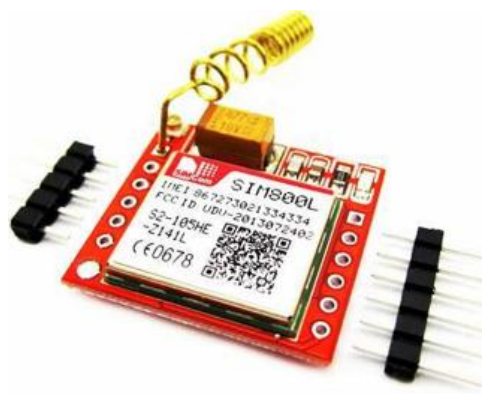

Gambar 4 Modul SIM800L.

\section{METODOLOGI}

Penelitian ini dilakukan di Labolatorium FT UMT, Bulan September Desember 2018. Bahan yang digunakan dalam perancangan tugas ini meliputi: Arduino Nano, Modul LM2596, LCD 16x2, LED merah, Sensor MQ-2, Buzzer, Modul SIM800L, dan 
Smartphone Android sebagai media monitoring data dari gas. Alat pendukung yang digunakan meliputi: Papan PCB lubang, Solder, Timah, Penyedot timah, Cutter, Tang potong, Multitester, dan kabel USB untuk power dan transfer data Arduino. berikut:

Prosedur Penelitian, dilakukan sebagai

\section{a. Blok Diagram Alat}

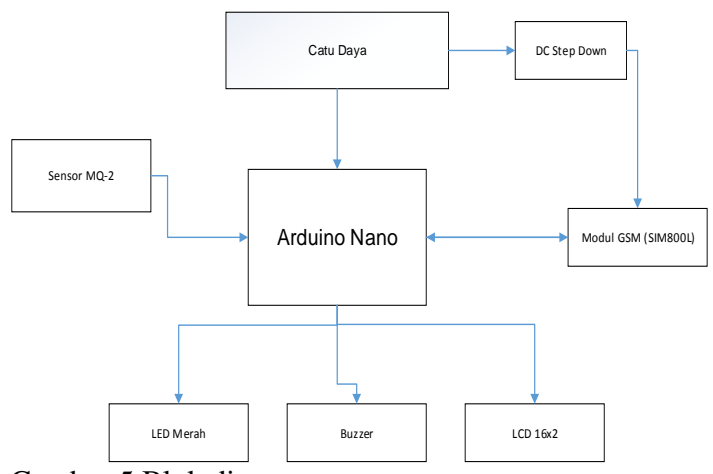

Gambar 5 Blok diagram system.

Berdasarkan Blok diagram yang telah dibuat dapat dijelaskan secara garis besar prinsip kerja alat pendeteksi kebocoran gas berbasis Arduino nano:

1. Ketika alat dinyalakan pertama pengecekan modul gsm sampai modul gsm mendapatkan sinyal dan di LCD tertera "GSM OK".

2. Jika sensor MQ-2 mendeteksi keberadaan gas LPG maka Sensor MQ-2 akan memberikan sinyal analog ke Arduino melalui pin Input Analog.

3. Selanjutnya sinyal anolog tersebut di ubah menjadi sinyal digital oleh converter yang ada pada Arduino sehingga sinyal tersebut dapat di proses sesuai dengan logika program

4. Kemudian mikrokontroler arduino akan memberikan perintah pada LED, Buzzer dan Exhaust Fan untuk aktif (On) sesuai dengan logika pada program. LED disini berfungsi sebagai indikator, Buzzer sebagai alarm dan Modul GSM berfungsi untuk memberikan data kadar gas dan juga sebagai indicator melalui sms jika kadar gas dalam ruangan bocor.

Secara keseluruhan sistem terdiri dari input, proses dan output. Yang mana Input adalah sensor MQ-6. Proses adalah Mikrokontroler Arduino dan output adalah LED, Buzzer dan Exhaust Fan.

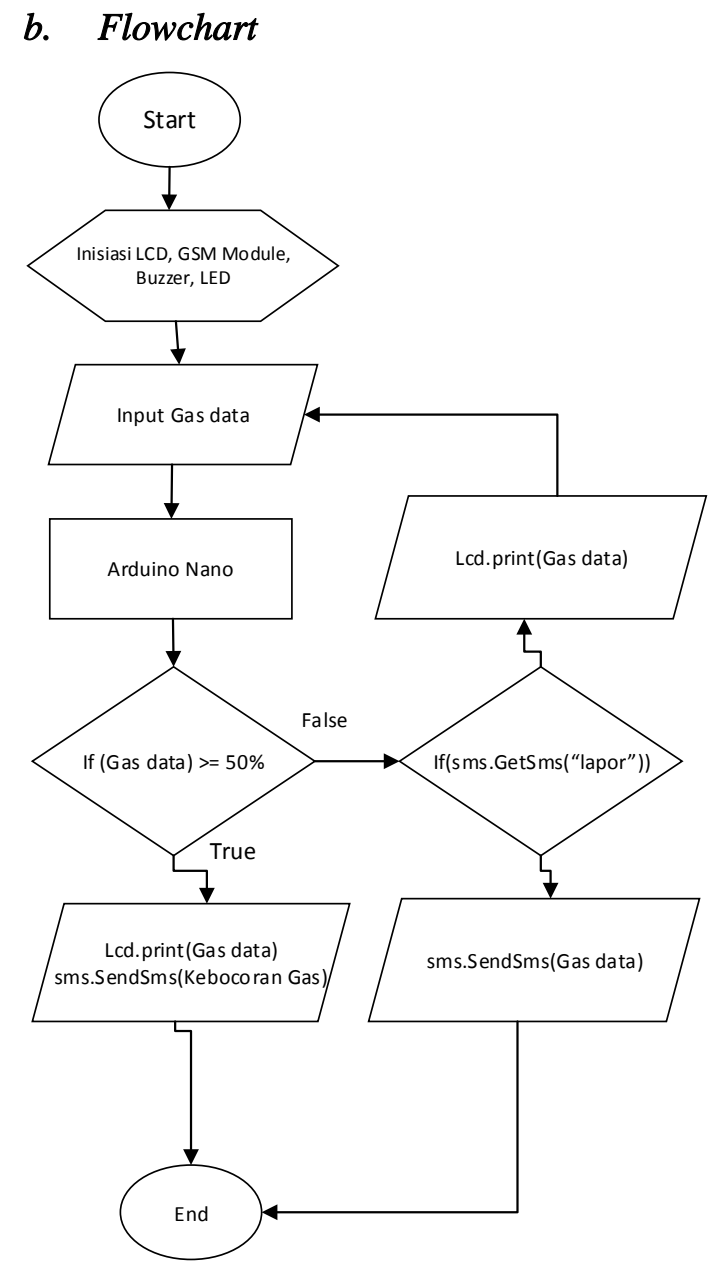

Gambar 6 Flowchart Prosedur Pengujian.

Penjelasan mengenai Flowchart sebagai berikut: 1) Alat di nyalakan, 2) Inisiasi semua komponen yang terdapat pada alat, 3) Alat membaca kadar gas dalam ruangan dan kemudian di proses oleh Arduino, 4) Jika kadar gas dalam ruangan sudah mencapai lebih dari 50\% maka LCD dan Modul GSM mengirimkan sms ke nomor yang dituju dan tertera kebocoran gas dengan kadar gas tersebut, 5) Ketika modul gsm mendapatkan sms tertulis "lapor" maka alat akan mengirimkan data kadar gas dalam ruangan ke nomor yang di tuju.

\section{c. Desain Hardware}

Berikut desain hardware alat pendeteksi kebocoran gas dalam ruangan berbasis Arduino nano menggunakan software solidworks. 


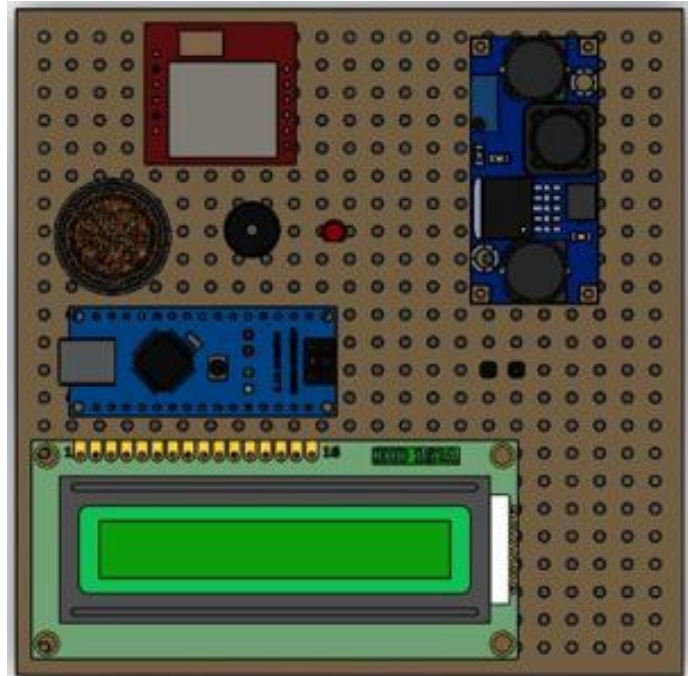

Gambar 7 Desain Hardware.

\section{d. Desain Software}

Berikut desain software alat pendeteksi kebocoran gas dalam ruangan berbasis Arduino nano. Ada beberapa desain software yang di tampilkan yaitu menggunakan software Arduino dan Eagle. Desain Software menggunakan Eagle (Desain PCB).

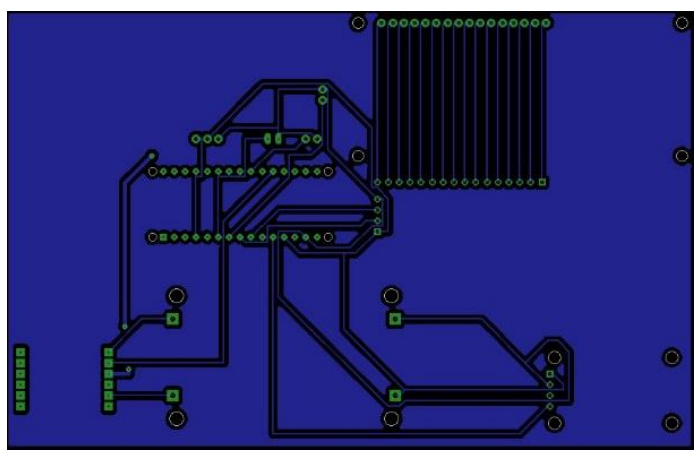

Gambar 8 Desain PCB.

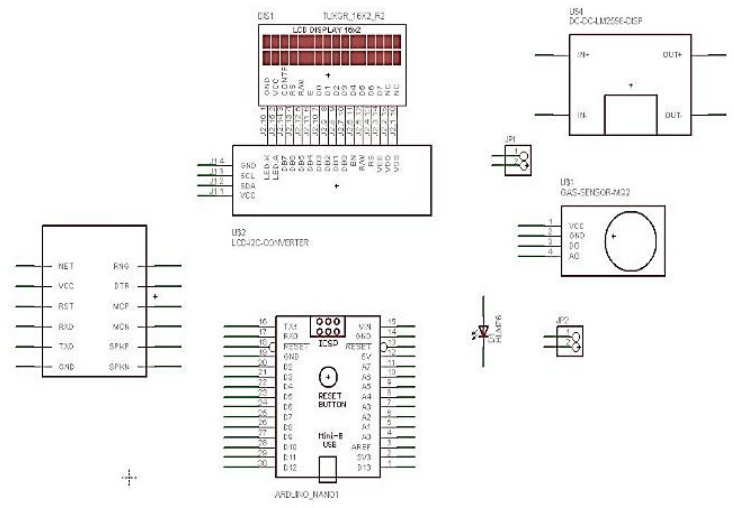

Gambar 9 Desain Software Wiring Komponen.

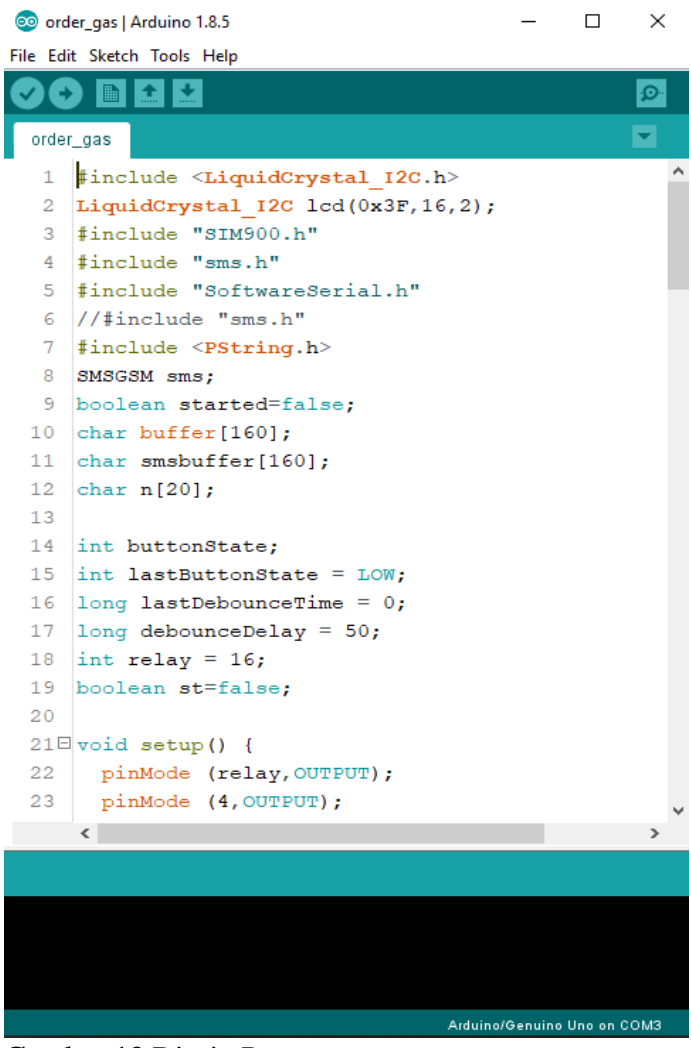

Gambar 10 Disain Program.

\section{e. Perancangan Perangkat Keras (Hard- ware)}

Perancangan perangkat keras (hardware) meliputi elektronik seperti rangkaian catu daya (power supply), rangkaian sensor, rangkaian mikrokontroller, rangkaian LED.

Berikut adalah bahan-bahan yang digunakan dalam perancangan perangkat keras:

\begin{tabular}{|l|c|}
\hline \multicolumn{1}{|c|}{ Nama Barang } & Unit \\
\hline Sensor MQ-2 & 1 \\
\hline Modul GSM & 1 \\
\hline Papan PCB bolong & $1(7 \mathrm{~cm} \mathrm{x} 8 \mathrm{~cm})$ \\
\hline LCD & 1 \\
\hline Modul DC Step Down & 1 \\
\hline Buzzer & 1 \\
\hline LED & 1 \\
\hline
\end{tabular}

Berikut gambar hasil dari pemasangan komponen-komponen pada alat: 


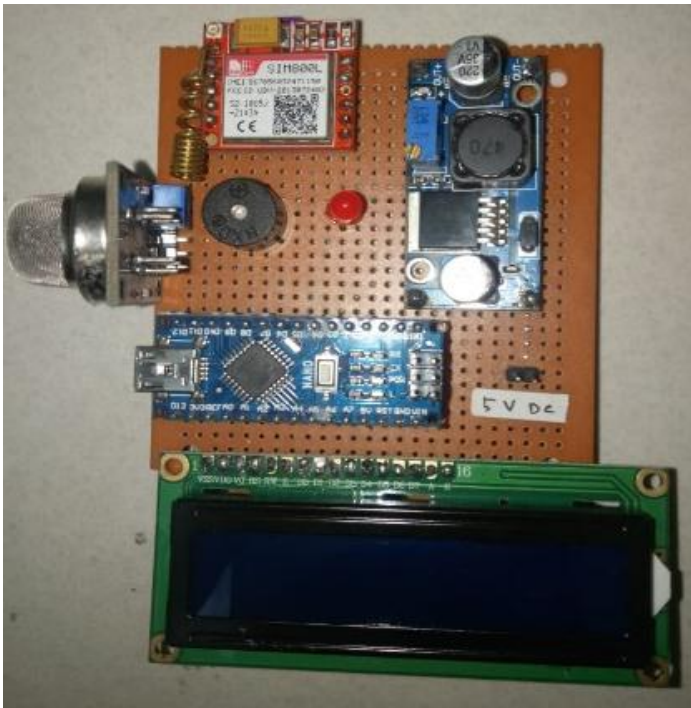

Gambar 11 Prototipe Pendeteksi Kebocoran Gas

\section{HASIL DAN PEMBAHASAN}

a. Pengujian Perangkat Keras (Hardware)

Pengujian SIM800L dibutuhkan untuk mengetahui apakah SIM800L dapat bekerja sebagaimana mestinya yaitu bisa berkomunikasi dengan Android melewati SMS. Berikut hasil pengecekan dari SIM800L

Tabel 1 Pengiriman SMS Ke Android.

\begin{tabular}{|c|c|c|c|}
\hline SIM800L & $\begin{array}{c}\text { Respon } \\
\text { Time }\end{array}$ & $\begin{array}{c}\text { Serial } \\
\text { Monitor }\end{array}$ & Android \\
\hline Send("test") & 2 & $\begin{array}{c}\text { SMS } \\
\text { terkirim }\end{array}$ & Receive("test") \\
\hline Send("test") & 1 & $\begin{array}{c}\text { SMS } \\
\text { terkirim }\end{array}$ & Receive("test") \\
\hline Send("test") & 2 & $\begin{array}{c}\text { SMS } \\
\text { terkirim }\end{array}$ & Receive("test") \\
\hline
\end{tabular}

Tabel 2 Pengiriman SMS dari Android Ke Modul GSM.

\begin{tabular}{|c|c|c|}
\hline Android & $\begin{array}{c}\text { Respon } \\
\text { Time }\end{array}$ & Serial Monitor \\
\hline Send("1") & 3 & $\begin{array}{c}\text { Sms masuk dari: 087772632794 } \\
\text { ("1") }\end{array}$ \\
\hline Send("test") & 2 & $\begin{array}{c}\text { Sms masuk dari: 087772632794 } \\
\text { ("test") }\end{array}$ \\
\hline Send("asoy") & 2 & $\begin{array}{c}\text { Sms masuk dari: } 087772632794 \\
\text { ("asoy") }\end{array}$ \\
\hline
\end{tabular}

\section{b. Pengujian LCD dan I2C}

Rangkaian LCD 16x2 digunakan untuk menampilka data yang telah dari sensor gas. LCD disambungkan dengan I2C, kemudian modul I2C dihubungkan dengan pin A4, A5, Vcc, dan ground pada mikrokontroller Arduino nano.

Pengujian ini bertujuan untuk mengetahui apakah LCD dapat bekerja dan dapat digunakan. Gambar pengujian LCD dapat dilihat pada gambar dibawah:

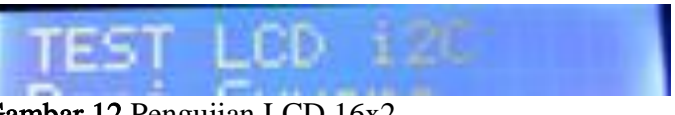

Gambar 12 Pengujian LCD 16x2.

Berdasarkan hasil pengujian pada lcd bekerja dengan baik, karena pada listing program tulisan "TEST LCD I2C" di atur pada posisi baris pertama dan posisi kolom 0 .

\section{c. Pengujian rangkaian LED indikator}

Pengujian Led dilakukan dengan cara menghubungkan anoda pada pin output Arduino yang melewati resistor terlebih dahulu dan katoda dihubungkan ke ground pada arduino. Lalu berikan logika program yaitu program kontrol On-Off (Logika High atau Logika Low). Led akan on jika diberikan logika High dan Off jika diberikan logika low.

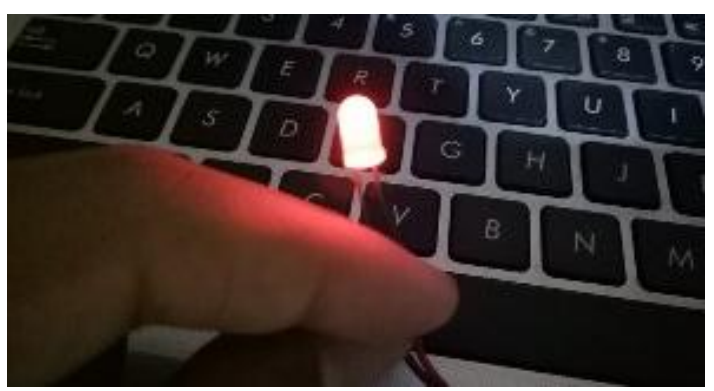

Gambar 13 Pengujian LED.

\section{d. Pengujian buzzer}

Pengujian Buzzer dilakukan dengan memberikan 2 input yaitu push button sebagai on dan off pada buzzer, polaritas positif pada buzzer dihubungkan dengan pin 5 pada Arduino nano dan polaritas negative dihubungkan dengan ground, untuk pin input dihubungkan dengan pin 3 sebagai on (PB1) dan pin 4 sebagai off (PB2) pada buzzer. Berikut program yang digunakan untuk mengaktifkan buzzer

Tabel 3 Pengujian Pada Buzzer.

\begin{tabular}{|c|c|c|c|}
\hline PB1 & PB2 & Buzzer & Teganan Pada Buzzer \\
\hline on & off & on & $4 \mathrm{~V}$ \\
\hline on & off & on & $3,8 \mathrm{~V}$ \\
\hline off & on & off & $0 \mathrm{~V}$ \\
\hline off & on & off & $0 \mathrm{~V}$ \\
\hline
\end{tabular}

\section{e. Pengujian sensor $M Q-2$}

Pengujian sensor gas (MQ-2) dilakukan untuk mengetahui apakah sensor gas dapat mendeteksi gas dengan baik untuk satuan yang digunakan dalam sensor gas adalah ppm (Part Per Milion) yaitu satuan dalam mengukur kepekaan dalam suatu gas atau cairan. Dalam proses pengecekan sensor gas digunakan LCD untuk memonitor kadar gas yang 
dikandung dalam sensor gas. Untuk mengecek sensor gas digunakan program sebagai berikut:

Dari program di atas yang sudah di upload aka nada hasil pengamatan dari sensor gas. Berikut data hasil pengecekan sensor gas.

Tabel 4 hasil dari sensor gas

\begin{tabular}{|c|c|}
\hline LCD & Volt pada MQ-2 \\
\hline Kadar Gas: $155 \mathrm{ppm}$ & $0,6 \mathrm{~V}$ \\
\hline Kadar Gas: $165 \mathrm{ppm}$ & $0,6 \mathrm{~V}$ \\
\hline Kadar Gas: $552 \mathrm{ppm}$ & $1,8 \mathrm{~V}$ \\
\hline Kadar Gas: $304 \mathrm{ppm}$ & $1,2 \mathrm{~V}$ \\
\hline Kadar Gas:789 ppm & $2 \mathrm{~V}$ \\
\hline
\end{tabular}

\section{f. Pengujian keseluruhan pada alat}

Pengujian keseluruhan pada komponen alat dilakukan agar semua berjalan dengan baik ketika digunakan pada kondisi sebenarnya, dengan menggabungkan semua komponen dan program LCD, Sensor Gas, SIM800L, Buzzer, dan LED ke mikrokontroller Arduino nano. Untuk pengujian alat tersebut digunakan program sebagai berikut:

Tabel 5 Pengujian secara keseluruhan.

\begin{tabular}{|c|c|c|c|c|c|}
\hline No. & MQ-2 & LED & Buzzer & LCD & SIM800L \\
\hline 1 & $12 \%$ & Off & Off & $\begin{array}{c}\text { Detektor Gas } \\
\text { SMS kadar 12\% }\end{array}$ & Off \\
\hline 2 & $28 \%$ & Off & Off & $\begin{array}{c}\text { Detektor Gas } \\
\text { SMS kadar 28\% }\end{array}$ & Off \\
\hline 3 & $37 \%$ & Off & Off & $\begin{array}{c}\text { Detektor Gas } \\
\text { SMS kadar 37\% }\end{array}$ & Off \\
\hline 4 & $49 \%$ & Off & Off & $\begin{array}{c}\text { Detektor Gas } \\
\text { SMS kadar 49\% }\end{array}$ & Off \\
\hline 5 & $52 \%$ & On & On & $\begin{array}{c}\text { Detektor Gas } \\
\text { SMS kadar 52\% }\end{array}$ & $\begin{array}{c}\text { Gas Bocor } \\
\text { Dengan Kadar } \\
52 \%\end{array}$ \\
\hline 7 & $62 \%$ & On & On & $\begin{array}{c}\text { Detektor Gas } \\
\text { SMS kadar 62\% }\end{array}$ & $\begin{array}{c}\text { Gas Bocor } \\
\text { Dengan Kadar } \\
62 \%\end{array}$ \\
\hline 7 & $65 \%$ & On & On & $\begin{array}{c}\text { Detektor Gas } \\
\text { SMS kadar 65\% }\end{array}$ & $\begin{array}{c}\text { Gas Bocor } \\
\text { Dengadar Kan } \\
65 \%\end{array}$ \\
\hline
\end{tabular}

\section{KESIMPULAN}

1. Sensor MQ-2 merupakan sensor yang cocok dipakai sebagai pendeteksi kebocoran gas pada alat proteksi kebocoran gas LPG dikarenakan sensitif terhadap gas butana yang merupakan kandungan utama dari LPG.

2. Tegangan output sensor MQ-2 berbanding lurus dengan kenaikan nilai volt. Pada data pengujian saat kadar gas dalam sensor sebesar $155 \mathrm{ppm}$ nilai tegangan output pada sensor adalah 0,6 ketika kadar gas naik pada sensor output yang dikeluarkan pada sensor juga ikut bertambah.
3. Alat yang telah dibuat yaitu alat pendeteksi kadar gas dalam ruangan berbasis Arduino nano berhasil dengan baik. Bisa diliha dari data hasil pengamatan pada uji coba keseluruhan alat semuanya terintegrasi berfungsi dengan sebagaimana mestinya.

\section{DAFTAR PUSTAKA}

Agung, F. S., Farhan, M., Rachmansyah, \& Widiyanto, E. P. (2009). Sistem Deteksi Asap Rokok Pada Ruangan Bebas Asap Rokok Dengan Keluaran Suara. Teknik Komputer, 1-9. https://doi.org/10.1287/ mnsc.32.4.403

Al-fuqaha, A., Member, S., Guizani, M., Mohammadi, M., \& Member, S. (2015). $<$ Internet of Thing A Survey on Enabling tec pro app.pdf >, 17(4), 23472376. https://doi.org/10.1109/COMST. 2015.2444095

Amalia, G. R., \& Aprilianto, H. (n.d.). Sistem Deteksi Kebocoran Gas LPG Berbasis Mikrokontroller Atmegal6.

Avrilyantama, H., Rivai, M., \& Purwanto, D. (2015). Pengembangan Robot Hexapod untuk Melacak Sumber Gas, 4(1), 1-6.

Barovih, G., Ardianto, R., Siregar, S. I., \& Pratama, S. (2016). Penerapan Teknologi Pendeteksi Kebocoran Liquified Petrolium Gas Berperingatan Alarm dan SMS. Sisfotenika, 6(1), 91-101.

David, N., Chima, A., Ugochukwu, A., \& Obinna, E. (2015). Design-of-a-HomeAutomation-System-Using-

Arduino.doc. International Journal of Scientific \& Engineering Research, 6(6), 795-801. Retrieved from https://www.ijser.org/researchpaper/De sign-of-a-Home-Automation-SystemUsing-Arduino.pdf

Dewi, S. S., Satria, D., Yusibani, E., \& Sugiyanto, D. (2017). Sistem Deteksi Kebakaran Pada Kasus Kebocoran Gas Berbasis Sms Gateway. Seminar Nasional II USM 2017, 1, 106-109.

Erlansyah, D. (2014). Rancang Bangun Alat Deteksi Kebocoran Tabung Gas Elpiji Berbasis Arduino. Universitas Bina Darma, Palembang, 2014 (November), 
$1-7$.

https://doi.org/10.1136/jme.13.2.81

Isnaini, V. A. (2013). Pemanfaatan Modul Mikrokontroller Arduino Untuk Rancang Bangun Alat Ukur Fisika. EduPhysic Vol. 4, Tahun 2013, 4, 116-125.

Joko, C., \& Nurul, K. (2013). Prototipe Sistem Pendeteksi Kebocoran Gas LPG Menggunakan Sensor Gas MQ2, Board Arduino Duemilanove, Buzzer, dan Arduino GSM Shield pada PT. Alfa Retailindo (Carrefour Pasar Minggu). Ticom, 2(1), 58-64. Retrieved from https://www.neliti.com/id/publications/ 92830/prototipe-sistem-pendeteksikebocoran-gas-lpg-menggunakansensor-gas-mq2-board-a

Nasional, S., Informasi, T., Prasetyo, A., Raharjo, I. M., Informatika, M. T., Pemadam, D., ... Banyumas, K. K. (2016). Alat Pendeteksi dan Pengaman Kebocoran Gas Lpg Melalui Sms Berbasis Mikrokontroler Atmega328, 30-35.

P, N. P. A., \& Vanamala, C. K. (2018). Wireless Sensor Network ( WSN) based weather monitoring in flood disaster management by using IOT, 25(6), 2732.

Prakoso, M. A. A., \& Rakhmawati, L. (2018). Sistem Monitoring Kadar Karbon Monoksida ( Co ) Pada Cerobong Asap Industri Dengan Komunikasi Bluetooth Melalui Smartphone Android Lusia Rakhmawati Abstrak. Jurnal Teknik Elektro, 07(01), 23-30.
Putra, A. N. (2016). Sistem Otomasi Pengering Pakaian Berbasis Mikrokontroller Arduino. Journal SAINTEK, 13(2), 70.

Roihan, A., Permana, A., \& Mila, D. (2016). Monitoring Kebocoran Gas Menggunakan Mikrokontroler Arduino Uno dan ESP8266 Berbasis Internet of Things. ICIT (Innovative Creative and Information Technology), 2(2), 170-183.

Saefullah, A., Syahrial, H., \& Santoso, A. (2012). Mikrokontroller At89S2051, 2012 (Semantik), 18-25.

Soemarsono, B. E., Listiasri, E., \& Kusuma, G. C. (2015). Alat Pendeteksi Dini Terhadap Kebocoran Gas LPG. Jurnal Tele, 13(1), 1-6.

Widarto, Z. K., Rakhmawati, R., Teknik, M., Industri, E., Industri, T. E., Elektronika, P., \& Surabaya, N. (2012). Pendeteksi Dan Pengamanan Kebocoran Gas Lpg (Propana) Berbasis Mikrokontroller. Teknik Elektro Industri, Politeknik Elektronika Negeri Surabaya Institut Teknologi Sepuluh Nopember Surabaya, 1-6.

Yanti, N. (n.d.). Implementasi Programable Logic Control Dan Wonderware Intouch Untuk Otomasi Smart Home, 2(1), 55-60. 